\title{
Relationship between X-Ray Pattern and Defects-Distribution in a Polymer Crystal(Abstract_要旨 )
}

\author{
AUTHOR(S): \\ Amano, Toshihiko
}

\section{CITATION:}

Amano, Toshihiko. Relationship between X-Ray Pattern and Defects-Distribution in a Polymer Crystal. 京都大学, 1966, 理学博士

\section{ISSUE DATE:}

1966-09-27

URL:

http://hdl.handle.net/2433/211998

RIGHT: 


\section{【40】}

氏名 天 $\begin{array}{ccc}\text { 天野 敏彦 } \\ \end{array}$ 学位の種類理学博士 学位記番号論 理 博 第 154 号 学位授与の日付昭 和 41 年 9 月 27 日

学位授与の要件学 位規則第 5 条第 2 項該当

学位論文題目 Relationship between X-Ray Pattern and DefectsDistribution in a Polymer Crystal

(高分子結晶内の欠陥の分布とX線像との関係) (主 查)

論文調査委員教 授田中憲三 教 授 内田洋一 教 授 松原武生 教 授 長谷田泰一郎

\section{論 文内容 $の$ 要 旨}

実在の高分子結晶には金属等にみられる力と同様の欠陷が存在する。てれらはX線像に対するその性質 によって格子成分の乱れと格子点の位置の乱れの2種類に大別される。格子点の位置の乱れは Hooemann らによって研究され, 乱れとそのような乱れを含む結晶によるX線像との関係もかなり解析されている が, 格子成分の乱れに関しては十分研究されているとはいえなかった。

主論文は高分子結晶中で格子成分の乱れとなるような要因を考察し，そのような乱れをむつ結晶による X線回折像について論じたあのである。低分子結晶特に金属にあってはこの種の乱れは積層欠楩，合金の 秩序無秩序構造, 固溶体等の問題として以前から論じられているが, てれらと同様の考え方を鎖状高分子 結晶に適用したあのである。

まず，鎖状高分子において鎖にそった欠陥の分布確率を導入した。乙の確率は高分子の場合重合の際の 条件によって決まるあのが多い。乙の確率を用いると高分子結晶の乱れは $\left(\mathrm{P}_{11}-\mathrm{P}_{21}\right)$ （正規の単位の次に 正規の単位がくる確率と欠陥のつぎに正規の単位がくる確率との差）をパラメーターとして三つの特徽的 な場合に分類され，それぞれ異なったX線像を与えることがわかる。

1） $1 \geq\left(\mathrm{P}_{11}-\mathrm{P}_{21}\right)>0$ この場合欠陥は結晶内でブロック的に分布し，そのような結晶によるX線像は欠陥 を全く含まないとした仮想的な規則格子からの反射のほかに各層線上に線条を生じる。

2) $\left(\mathrm{P}_{11}-\mathrm{P}_{12}\right)=0$ この場合欠陥は結晶内で全く不規則に分布し，その X線像は仮想的な規則格子からの 反射のほかに背景に散漫散乱が現われる。

3) $0>\left(\mathrm{P}_{11}-\mathrm{P}_{21}\right) \leq-1$ 乙の場合欠陥は正規の単位と交互に分布する傾向があり，X線像は仮想的な規則 格子からの反射のほかに各層線間に幅の広い散乱が現われる。

以上はX線強度分布の理論的な計算の結果得られたものであるが, さらにてれを光学モデルを用いて確 認した。乙のモデルは紙上に上記三つの場合にしたがって正規単位（ある文字）と欠陥（空所）をそれぞ れ配分した活字列を多数平行に配置してタイプし，てれを写真フィルムに縮写したあのである。なお，活 
字列に直角な方向の欠陷の分布はいずれの場合も不規則にしてある。てのような三つのモデルにそれぞれ

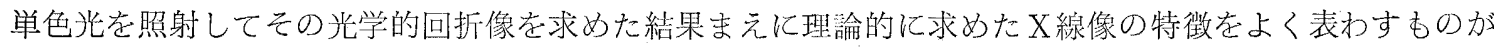
得られた。

との理論が適用できる例として高度に配向させたイソタクティック・ポリプロピレンのX線像の各層線 にみられる線条について考察した。ての線条は温度によって変化しないとと，高次のブラッグ反射がほと んどぼけていないととろから温度散乱または格子点の位置の乱れにもとづくあのではなく，上記三つの場 合のうち欠宿が鎖の中でブロック的に分布する場合に相当する屯のと解される。とれも光学モデルを用い て類推している。な怙,このときの欠陥としては分子の立体規則性の乱れ等が十分考えられるとしている。

また，この理諭は絬晶中の格子成分の乱れとみなせるような構造特に重合体の同型や共重合体の成分単 重体の分布状態を研究するための一つの手がかりを与えるものと論じている。

\section{論 文 審 査の 結 果 の 要旨}

実在の結晶には種々の型の欠陌が存在する。その種類決定と結晶内での分布状態についての研究は数多 くなされているが，その大部分は金属その他の低分子物質の結晶についてである。高分子結晶に执いても 格子点の位置の乱れによる欠陥についてはX線的にあある程度解析されているが，格子成分の乱れによっ て生ずる欠宿についてのX線的研究はほとんど見られない。本論文は後者に属するあので，鎖状高分子の 結晶内の格子成分の乱れの分布をX線回折像から推定したものである。

そのため鎖にそった方向の欠陷の分布確率の考学学入して，3種の代表的分布についてそれぞ理論 的に予想されるX線回折像の強度分布の特徵を求めた。つぎにそれら 3 種の分布に対応する光学モデルを つくり，それを用いて光による回折実験を行なって，それぞれの場合に予想された特徽があるてとを確か めた。

この方法を実際の場合に忘用するため, 高度に配向させたイソタクティック・ポリプロピレンのX線回 折像をとり，てれと光学モデル写真との比较から，ての場合の欠楩は分子鎖中で小集団在なして不規則に 点在するものであると推定した。

以上のように，乙の主論文は高分子結晶に括ける格子成分の乱れによる久陷の分布とX線回折像との関 係を理論的にまたモデル実験によって解明するという数少ない研究で, 論旨を妥当で実験屯興味深いもの であり，ての分野に拉ける広い応用屯期待され，その発展に寄与するととが少なくない。

よって本論文は理学博士の学位論文として洒值があるものと認める。 